taxonómica, sinonimia actualizada y lectotipificaciones cuando fue necesario. El análisis filogenético, realizado bajo el principio de la máxima parsimonia, reveló que Cenchrus constituye un grupo monofilético, definido por la presencia de setas estériles que caen junto con las espiguillas, una vez alcanzada la madurez de las mismas. Futuros estudios incorporando caracteres moleculares permitirán ampliar la información existente y lograr una sólida hipótesis filogenética del grupo.

\section{Studies of the American species}

of the genus Cenchrus $L$ (Poaceae:

Panicoideae: Paniceae)

\section{Summary}

Recent phylogenetic studies provided evidence on the monophyly of the genera Cenchrus, Pennisetum and Odontelytrum proposing unification and transfer to the genus Cenchrus, which has priority. To date, there is no history to consider their taxonomic treatment together. The purpose of this study was to perform a taxonomic revision of the American species of the genus Cenchrus s.l. and test the utility of morphological characters in phylogenetic analyzes evalua- ted. As this study is limited to the American Continent, the Odontelytrum monotypic genus, native to Africa, was excluded from the analysis. For taxonomic revision, herbarium specimens were studied from institutions of Argentina and other countries. Prior to taxonomic treatment was analyzed morphological diversity in vegetative and reproductive structures of the species to identify diagnostic features that facilitate their subsequent determination, recognizing seven groups of species. The taxonomic treatment identified 41 species included in 7 infrageneric categories (6 sections and 2 subsections). Keys to recognize the related genera, the proposed Sections and all species that grow in America are given. In addition, are shown detailed descriptions of the species, illustrations of the characters of taxonomic importance, synonymy and lectotypifications. Phylogenetic analysis, carried out under the principle of maximum parsimony, revealed that Cenchrus constitutes a monophyletic group, defined by the presence of bristles falling with the spikelets, after reaching maturity. Future studies incorporating molecular characteristics allow expand existing information and to obtain a robust phylogenetic hypothesis of the group.

\title{
Construcción, diseño, análisis y puesta en funcionamiento de un foto-bio-reactor; modelado del campo radiante; de los fenómenos de transferencia y de la cinética de crecimiento de algas microscópicas de interés tecnológico
}

\author{
Josué Miguel Heinrich \\ heinrichmiguel@hotmail.com \\ Horacio Antonio Irazoqui \\ GiiB - Grupo de Innonación en Bioprocesos
}

Cátedra de Operaciones y Procesos Biotecnológicos. FBCB - UNL

Grupo de Operaciones y Procesos Biotecnológicos. INTEC-CONICET y UNL 
Laboratorio, Cátedra y/o Departamento: Cát de Operaciones y Procesos Biotecnológicos Facultad de Bioquímica y Ciencias Biológicas Universidad Nacional del Litoral

Fecha de la defensa: 04/12/2013

\section{Resumen}

La biotecnología de microalgas ha adquirido gran importancia en los últimos años debido a la gran cantidad de productos de interés que pueden obtenerse a partir de su cultivo. Estos productos van desde la propia biomasa para consumo animal o humano, hasta productos extraídos de su estructura como triglicéridos (potenciales materias primas para la producción de biodiesel), carotenoides, proteínas, productos bio-activos utilizados por la industria farmacéutica, etc. Por otro lado, la gran variedad de especies de microalgas existentes y los desarrollos en la ingeniería genética y metabólica posicionan al cultivo de microalgas como una plataforma biotecnológica de gran potencial para la producción de diversos productos de interés tecnológico y/o comercial.

A pesar del gran desarrollo logrado en los últimos tiempos, existen aún numerosos problemas que son necesario resolver a fin de lograr una tecnología de cultivo eficiente y rentable. Con este trabajo, se busca abordar la resolución de cuestiones asociadas al análisis de los foto-bioreactores en escala de laboratorio; principalmente en relación con el modelado del campo de energía radiante; el modelado de los fenómenos de transporte que ocurren dentro de los reactores; y, con la obtención de un modelo cinético que exprese la velocidad de crecimiento celular como una función de la disponibilidad de luz en el cultivo.

Los objetivos trazados intentan lograr el desarrollo de modelos que puedan utilizarse como base del diseño, optimización y cambio de escala de foto-bio-reactores. En tal sentido, se busca que los valores de los parámetros incluidos en el modelo y la funcionalidad del mismo con las diferentes variables sean invariantes e independientemente de la configuración de reactor utilizado.

Construction, design and analysis of photo-bio-reactors: modeling of the radiation field, the mass transfer phenomena and growth kinetics of microscopic algae

\section{Summary}

The microalgae biotechnology has acquired great importance in recent years due to the large number of products of interest which may be obtained from its culture. These products range from biomass for animal or human consumption, to products extracted from its structure such as triglycerides (potential raw materials for biodiesel production), carotenoids, proteins, bioactive compounds used by the pharmaceutical industry, etc. Moreover, due to the wide variety of existing microalgal species and the developments in genetic engineering and metabolic, microalgae have become a potential platform for the production of various products of technological interest.

Despite the great development achieved in recent times, there are still many problems that need to be solved in order to achieve a efficient cultivation technology. With this work, we seek to address the resolution of issues associated with the analysis of reactors at laboratory scale, mainly in relation to the modeling of radiant energy field, the modeling of the transport phenomena occurring within the reactors and obtaining a kinetic model that expresses the cell growth rate as a function of the light availability in the culture. 
The objectives outlined try to achieve the development of models that can be used as a basis for the design, optimization and scaling-up of photo-bio-reactors. In this sense, it is intended that the values of the parameters included in the models and its functionality with the different variables of the system do not depend on the reactor configuration.

\section{Modelado matemático de la liberación controlada de fármacos desde dispositivos vaginales de tipo matriz monocapa con geometría de toro}

\author{
Ignacio Marcelo Helbling \\ ihelbling@santafe-conicet.gov.ar \\ Julio Alberto Luna \\ María Inés Cabrera \\ INTEC I - CCT CONICET Santa Fe \\ Laboratorio de Química Fina \\ Facultad de Bioquímica y Ciencias Biológicas \\ Universidad Nacional del Litoral \\ Fecha de la defensa: 13/03/2013
}

\section{Resumen}

El diseño, desarrollo y el uso de los anillos vaginales han tenido creciente relevancia y atención en la ciencia, en la industria y en la sociedad en general. Esta tecnología está recién en sus inicios y se espera que en los próximos años tenga un rol preponderante en la industria farmacéutica. El empleo de un modelo matemático como herramienta para guiar el desarrollo y optimización de estos dispositivos de liberación controlada, es un factor clave en el avance y en el establecimiento de esta tecnología.

A este respecto, el desarrollo de un modelo matemático fiable capaz de predecir la cinética de liberación desde los anillos vaginales fue el objetivo central del presente trabajo. El modelo desarrollado se validó rigurosamente mediante comparación con perfiles experimentales obtenidos en nuestro laboratorio y con datos reportados en la bibliografía por otros autores. El uso de este modelo permite estudiar la liberación controlada de solutos desde los anillos mediante simulaciones computacionales, evitando así los inconvenientes propios de la experimentación in vitro e in vivo.

El modelo desarrollado se empleó con éxito para predecir la liberación de diversos solutos hormonales, abarcando en dicha tarea, la variación del polímero que conforma la matriz de los dispositivos, la variación de parámetros de diseño como la carga inicial de soluto y las dimensiones de los anillos, la variación de parámetros experimentales como la velocidad de agitación y el medio de liberación, entre otros. Los resultados exitosos obtenidos en este amplio rango de ensayos permiten aseverar la validez y utilidad del modelo desarrollado.

Finalmente, el modelo desarrollado se empleó con éxito para la optimización de un dispositivo comercial conocido. El uso del modelo posibilitó hacer comparaciones y estudios mediante simulaciones computacionales, que sentaron las bases para mejorar un anillo vaginal existente. Por todo ello, se puede concluir que el empleo del modelo matemático desarrollado es una herramienta invaluable en los procesos de 